\title{
Plumboporphyria (ALAD deficiency) in a lead worker: a scenario for potential diagnostic confusion
}

\author{
J Dyer, D P Garrick, A Inglis, I F Pye
}

\begin{abstract}
A lead worker developed bilateral wrist drop. At first this seemed to be a lead neuropathy but all his screening tests for blood and urine toxicity had been within the accepted safety limit during employment. Detailed investigation showed that he had plumboporphyria (ALAD deficiency) which had been symptom free until he was exposed to lead. Details of his porphyrin metabolism are presented.
\end{abstract}

(British fournal of Industrial Medicine 1993;50:1119-1121)

Plumboporphyria, $\delta$-aminolaevulinic acid dehydratase deficiency (ALAD deficiency), is a rare disorder of porphyrin metabolism. We record the case of a man in whom the condition only came to light after industrial exposure to lead that precipitated clinical manifestations. At presentation this was a diagnostic puzzle that was solved by an investigation of his porphyrin metabolic pathway.

\section{Case history}

A 30 year old white man of Dutch extraction presented to his general practitioner in August 1990 with bilateral wrist drop and weakness of the hands that had developed over four days and was referred for an urgent neurological opinion. For 18 months he had been employed at a factory making batteries, initially in the battery assembly department and then from June 1990 he had worked with lead. His job involved the handling of lead plates in the plate preparation department for which he wore full factory clothing including gloves. The process and environmental control did not require respiratory protection. The work was heavy and the painless weakness of the wrists and hands developed over four days after a particularly strenuous period of

Departments of Neurology and Clinical Biochemistry, Leicester Royal Infirmary, Leicester LE1 5WW

J Dyer, D P Garrick, A Inglis, I F Pye activity. There were no other neurological symptoms and in particular there had been no disturbance of sensation. Systematic enquiry indicated good general health with no serious illnesses in the past. The patient's mother had developed diabetes mellitus when adult, but there was no other relevant family history. He was on no medication, smoked 15 cigarettes daily, and drank up to 10 units of alcohol a week.

General examination was normal. There was bilateral wrist drop with power in the wrist extensors of Medical Research Council grade 3, and weakness of extension of the fingers and thumbs (power, MRC grade 2). Sensation was intact and the remainder of the neurological examination was normal.

Nerve conduction studies showed a pronounced neuropathy of both radial nerves with axonal damage maximal distally. Also, there was electrophysiological dysfunction of the median nerves, right more than left, but only minor abnormalities of ulnar nerve function. Evidence of active denervation was found in the left extensor digitorum communis. Nerve conduction was normal in the lower limbs.

The patient stopped work after the onset of symptoms and there was no further exposure to lead. He remained well and was able to continue playing soccer. Over the next few months the weakness improved slowly. By August 1991 there was only minimal weakness of extension of the fingers and neurological examination was otherwise normal.

\section{Methods}

Red cell porphobilinogen deaminase was assayed by the method of Piepkorn et al. ${ }^{1}$ Red cell $\delta$ ALAD was assayed on freshly drawn blood by the EC standard method, ${ }^{2}$ which is essentially that of Collier. ${ }^{3}$ Blood lead concentration was determined by electrothermal atomic absorption with the method recommended by the CDC in Atlanta GA (Miller et $\mathrm{al}^{4}$. Urinary lead concentration was measured in a similar way by the technique of standard addition. 
Table 1 Blood lead concentrations

\begin{tabular}{lll}
\hline & \multicolumn{2}{l}{ Blood lead } \\
\cline { 2 - 3 } & $\mu g / 100 \mathrm{ml}$ & $(\mu \mathrm{mol} / \mathrm{l})$ \\
\hline Before employment & 25 & $(1 \cdot 21)$ \\
August 1989 & 39 & $(1 \cdot 88)$ \\
September 1989 & 30 & $(1 \cdot 45)$ \\
December 1989 & 26 & $(1 \cdot 26)$ \\
January 1990 & 24 & $(1 \cdot 16)$ \\
July 1990 & 39 & $(1 \cdot 88)$ \\
October 1990 & 22 & $(1 \cdot 06)$ \\
\hline
\end{tabular}

\section{Results}

The full blood count, plasma viscosity, serum vitamin $B_{12}$ and folate concentrations, serum biochemical profile, including blood glucose on several occasions, and tests of thyroid function were normal.

Urinary coproporphyrin III and blood lead concentrations had been monitored regularly. The coproporphyrin III concentration had fluctuated (possibly related to increased alcohol consumption) but at no time during employment had the blood lead been higher than $39 \mu \mathrm{g} / 100 \mathrm{ml}(1.88 \mu \mathrm{mol} / \mathrm{l})$. Table 1 shows the serial blood lead concentrations.

A lead mobilisation test was performed with intravenous infusion of disodium calcium EDTA $(25 \mathrm{mg} / \mathrm{kg}$ over one hour (total dose $1875 \mathrm{mg}$ )).

The urinary lead concentration before infusion was $216 \mathrm{nmol} / 24$ hours (equivalent to $1217 \mu \mathrm{g}$ of lead excreted). The ratio $\mu \mathrm{g}$ lead:mg EDTA (1217: 1875 ) was 0.65 (normal $\leqslant 0 \cdot 60$ ). Table 2 gives details of the investigations of porphyrin metabolism.

\section{Discussion}

The acute selective motor neuropathy of the upper limbs conformed to the classical pattern described in lead poisoning. Although the lead mobilisation test provided evidence of a marginally increased tissue load of lead, and the increased urinary porphyrins, porphobilinogen, $\delta$-ALA, and red cell protoporphyrin were consistent with lead poisoning, there were several features which caused the diagnosis to be questioned, prompting further investigation. Firstly, the patient was well with no other clinical features of lead toxicity, secondly, at no time had the blood lead been higher than $39 \mu \mathrm{g} / 100 \mathrm{ml}$ (the Health and Safety Executive regards $40 \mu \mathrm{g} / 100 \mathrm{ml}$ as the concentration at which industrial exposure begins to be potentially relevant), and thirdly, the blood count was normal with no features suggestive of lead intoxication. The possibility of an underlying disorder of porphyrin metabolism was considered. Acute intermittent porphyria was excluded by normal red cell porphobilinogen deaminase activity, but the red cell ALAD concentration was only $17 \%$ of the control value, and on the basis of this test it was concluded that the patient was heterozygous for ALAD deficiency (plumboporphyria). The reduced ALAD activity was not the result of inhibition by lead because the assay was performed when there had been no exposure for one year, the blood lead was normal at a concentration that would not cause significant inhibition of ALAD, and the patient had made a good recovery from the clinical neuropathy. There was no known relevant family history in this case. Although it would have been of interest to investigate other family members for evidence of ALAD deficiency, access to them has proved impossible because they live abroad.

ALAD deficiency was first recognised in $1979 .{ }^{5}$ It has an autosomal recessive inheritance and in the homozygous subject, in whom ALAD concentrae tions are less than $5 \%$ of normal, the clinical manifestations resemble those of acute intermittent porphyria and include acute abdominal pain, neuropathy, and anaemia. Heterozygous subjects usually have sufficient ALAD activity to prevent symptoms but it is recognised that they are vulnerable to the development of lead intoxication as a result of enzyme inhibition when there is only a moderate increase in blood lead concentration. ${ }^{67}$

In lead poisoning there is disturbance of porphyrin metabolism by inhibition of three enzymes in the haem biosynthetic pathway; ALAD, coproporphyrinogen oxidase and ferrochetolase. Red blood cell ALAD is very sensitive to inhibition by lead ${ }^{8}$ in a non-competitive manner, ${ }^{910}$ and it has been suggested that in chronic or low lead exposure measurement of both ALAD activity and blood lead is more useful than blood lead alone in the assessment of the severity of lead poisoning. ${ }^{10}$

Table 2 Porphyrin metabolism

\begin{tabular}{|c|c|c|c|}
\hline & 1 November 1990 & 16 August 1991 & Normal values \\
\hline $\begin{array}{l}\text { Urinary total porphyrins }(\mu \mathrm{g} / 24 \mathrm{~h}) \\
\text { Urinary porphobilinogen }(\mu \mathrm{mol} / 24 \mathrm{~h}) \\
\delta \mathrm{ALAD}(\mu \mathrm{mol} / 24 \mathrm{~h}) \\
\text { Red cell protoporphyrin }(\mathrm{nmol} / 1 \mathrm{RBC}) \\
\text { Porphobilinogen deaminase }(\mathrm{nmol} / \mathrm{ml} / \mathrm{l}) \\
\text { Red cell } \delta \mathrm{ALAD}(\mathrm{u} / 1 \mathrm{RBC})^{\star} \\
\text { Control }(\mathrm{u} / 1 \mathrm{RBC})^{\star}\end{array}$ & $\begin{array}{r}1490 \\
20 \\
490 \\
5742 \\
30 \cdot 7\end{array}$ & $\begin{array}{r}403 \\
3 \\
170 \\
-\quad \\
-\quad 4 \cdot 9 \\
29\end{array}$ & $\begin{array}{l}(0-300) \\
(0-16) \\
(0-4) \\
(70-925) \\
(24-49) \\
(29)\end{array}$ \\
\hline
\end{tabular}

${ }^{\star}$ Measured on 16 September 1991; faecal porphyrins were normal. 
We report this case because plumboporphyria is uncommon and is not a widely known disorder. The case is of interest because of the confusion that can arise when there is dispute about possible lead intoxication. It serves as a reminder that the diagnosis of lead poisoning may not be straightforward and assay of ALAD may be helpful when difficulties arise in an individual subject. Obviously it is important to establish whether an apparent example of lead poisoning has resulted from unacceptable and potentially avoidable exposure because safety regulations have been breached or monitoring has been inadequate, or whether a previously unsuspected inborn error of metabolism has rendered an individual susceptible to toxicity from only moderate increases of blood lead concentration. The distinction between these two situations could have important implications for financial compensation as an industrial injury. It is clear from our experience that the usual monitoring procedure for lead workers is incapable of detecting this disorder at a presymptomatic stage. The provision of routine pre-employment screening for ALAD deficiency in potential lead workers would pose considerable logistical as well as financial difficulties. The enzyme assay is not in routine use in clinical biochemical laboratories, it has to be performed on fresh specimens and therefore it would be impossible to send batches of specimens to a centralised specialist laboratory, and the number of positive results would be likely to be low. For these reasons it is probably impractical to consider such a screening programme and we have to conclude that from time to time cases similar to this one will arise and the lead poisoning will have a toxogenetic basis.

We are grateful to $\mathrm{Dr} M R$ Moore and staff, Porphyrias Service, Department of Medicine, Western Infirmary, Glasgow for advice and assistance.

1 Piepkorn MW, Hamernyik P, Labbe RF. Modified erythrocyte uroporphyrinogen. I synthase assay, and its clinical interpretation. Clin Chem 1978;24:1751-4.

2 Official fournal of the European Communities 1975; No C151/25. Brussels: Annex 2:25-29.

3 Collier HB. A study of the determination of $\delta$ ALA dehydratase activity in haemolysates of human erythrocytes. Clin Biochem $1971 ; 4: 222-32$.

4 Miller DT, Paschal DC, Gunter EW, Stroud PE, D'Angelo J. Determination of lead in blood using electrothermal atomisation atomic absorption spectrometry with a l'vov platform and matrix modifier. Analyst 1987;112:1701-4.

5 Doss M, von Tiepermann R, Schneider J, Schmid H. New type of hepatic porphyria with porphobilinogen synthase defect and intermittent acute clinical manifestation. Klin Wochenschr 1979;57:1123-7.

6 Doss M, Laubenthal F, Stoeppler M. Lead poisoning in inherited $\delta$-aminolevulinic acid dehydratase deficiency. Int Arch Occup Environ Health 1984;54:55-63.

7 Batlle AM del C, Fukuda H, Parera VE, Wider E, Stella AM. In inherited porphyrias, lead intoxication is a toxogenetic disorder. Int $\mathcal{F}$ Biochem 1987;19:717-20.

8 Wada O, Takeo K, Yano Y, Tetsu O, Nagahashi M, Seki H. $\delta$ aminolevulinic acid dehydratase in low level lead exposure. Arch Environ Health 1976;31:211-5.

9 Granick JL, Sassa S, Granick S, Levere RD, Kappas A. Studies in lead poisoning. II. Correlation between the ratio of activated to inactivated $\delta$-aminolevulinic acid dehydratase of whole blood and the blood lead level. Biochemical Medicine 1973;8:149-59.

10 Lolin Y, O'Gorman P. $\delta$-aminolevulinic acid dehydratase as an index of the presence and severity of lead poisoning in acute and chronic lead exposure. Ann Clin Biochem 1986;23:521-8.

Accepted 1 February 1993 